\title{
Multicomponent synthesis of artificial nucleases and their RNase and DNase activity
}

\author{
Anton V. Gulevich ${ }^{1}$, Lyudmila S. Koroleva ${ }^{2,3}$, Olga V. Morozova², \\ Valentina N. Bakhvalova ${ }^{4}$, Vladimir N. Silnikov ${ }^{* 2}$ \\ and Valentine G. Nenajdenko*1
}

\section{Full Research Paper}

Open Access

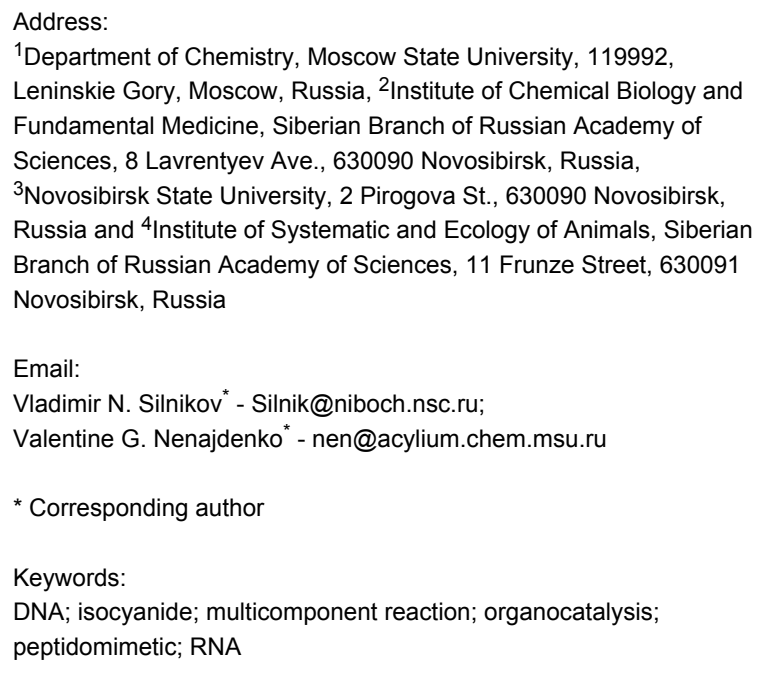

${ }^{1}$ Department of Chemistry, Moscow State University, 119992, Leninskie Gory, Moscow, Russia, ${ }^{2}$ Institute of Chemical Biology and Fundamental Medicine, Siberian Branch of Russian Academy of Sciences, 8 Lavrentyev Ave., 630090 Novosibirsk, Russia, ${ }^{3}$ Novosibirsk State University, 2 Pirogova St., 630090 Novosibirsk, Russia and ${ }^{4}$ Institute of Systematic and Ecology of Animals, Siberian Branch of Russian Academy of Sciences, 11 Frunze Street, 630091 Novosibirsk, Russia

Email:

Vladimir N. Silnikov* - Silnik@niboch.nsc.ru;

Valentine G. Nenajdenko* - nen@acylium.chem.msu.ru

* Corresponding author

Keywords:

DNA; isocyanide; multicomponent reaction; organocatalysis; peptidomimetic; RNA

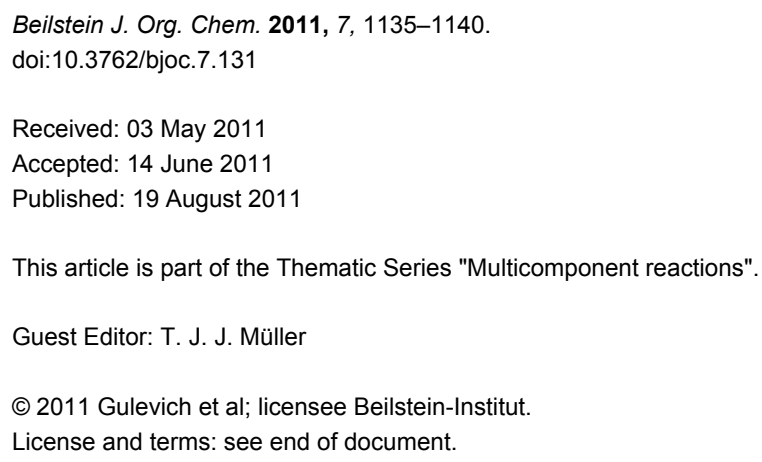

\section{Open Access}

\begin{abstract}
The synthesis of new, artificial ribonucleases containing two amino acid residues connected by an aliphatic linker has been developed. Target molecules were synthesized via a catalytic three-component Ugi reaction from aliphatic diisocyanides. Preliminary investigations proved unspecific nuclease activity of the new compounds towards single-stranded RNA and doublestranded circular DNA.
\end{abstract}

\section{Introduction}

RNA cleavage can serve as a molecular tool for biological research [1], as well as for development of anticancer drugs $[2,3]$ and new therapeutics against RNA-containing viruses. Recently, a number of synthetic RNA-cleaving molecules (artificial ribonucleases) had been developed and tested in vitro [4-11]. Among numerous artificial ribonucleases, peptidomime- tics showed evident advantages due to their lower cytotoxicity and elevated potential penetration into living eukaryotic cells. Moreover, a few dipeptides [12] were shown to induce interferon production, thus providing antivirus defence. Therefore, the development of new peptidomimetics with ribonuclease activity is an important task in organic and biomolecular chem- 
istry. In this paper we present the rational design, multicomponent synthesis, and RT-qPCR quantitation of nuclease activity of novel amino acids derivatives.

\section{Results and Discussion}

Recently, a number of artificial peptide ribonucleases modeling known catalytic centers of natural RNases A and T1 have been described [13-15]. RNA cleavage was shown to be more efficient in the presence of aliphatic hydrophobic linkers [16] However, the potential role of the alkyl chain of the catalyst remains unclear. Interaction of hydrophobic residues in peptides was suggested to result in formation of RNase mimetics in solution thus enhancing their ribonuclease activity. To prove this suggestion, symmetric aliphatic diamides $\mathbf{1}$ and $\mathbf{2}$ containing natural amino acid residues have been synthesized (Figure 1). The compounds showed high ribonuclease activity with model oligoribonucleotides and an HIV-1 recombinant RNA fragment 96 nucleotides long [17].<smiles>[R]C(N)C(=O)NCCCOCCCCOCCCNC(=O)C([R])N</smiles><smiles>[R]C(N)C(=O)NCCCCCCCCCCCCNC(=O)C([R])N</smiles>

Figure 1: Novel artificial RNases based on amino acids.

Previously, compounds $\mathbf{1}$ and $\mathbf{2}$ have been synthesized from the corresponding diamines by condensation with protected natural amino acids and subsequent deprotection [18]. This approach is significantly limited by using available natural amino acids ( $\mathrm{R}$ is a natural amino acid residue). Consequently, the development of new simple, atom-economic methods for the synthesis of this class of potential biologically active compounds is of great importance in bioorganic and medicinal chemistry. The development of multicomponent approaches is especially important because multicomponent reactions (MCR) could be adapted to a high throughput synthesis of libraries of compounds.

It is known that isocyanide-based MCR are very efficient for synthesis of peptides and peptide molecules [19-24]. We proposed that the desired compounds $\mathbf{5}$, containing two amide bonds and variable substituents, can be synthesized by the Ugi reaction with subsequent removal of diamine residue (Scheme 1). Original substrates for the synthesis could be ali- phatic diisocyanides $\mathbf{3}$, amines (with an easily removable protective group) and aldehydes. We used an organocatalytic three-component modification of the Ugi reaction, recently developed by List et al. [25]. The reaction results in diamines $\mathbf{4}$, thus avoiding the acid residue removal stage.<smiles>[R1]C(N)CCCCCCNC(=O)C([R])N</smiles>
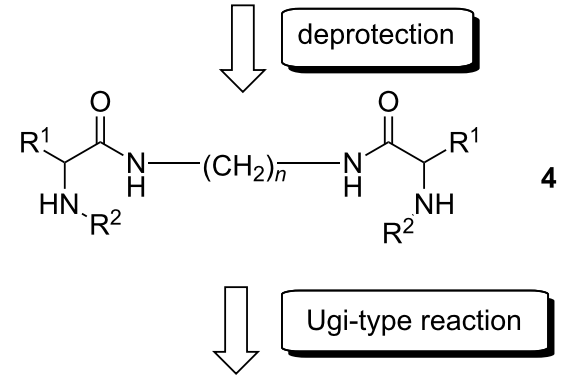

$$
\begin{array}{ccc}
\mathrm{CN}_{\left(\mathrm{CH}_{2}\right)_{n}{ }^{\prime} \mathrm{NC}} & + & \mathrm{R}^{2} \mathrm{NH}_{2} \\
& \mathrm{R}^{1} \overbrace{\mathrm{O}} &
\end{array}
$$

Scheme 1: Multicomponent approach to target molecules.

The starting diisocyanides 3 were obtained in good overall yields from commercially available diamines containing $6,7,8$, 10 or 12 carbon atoms by the standard formylation-dehydration protocol (Scheme 2).

$$
\begin{aligned}
& \mathrm{H}_{2} \mathrm{~N}-\left(\mathrm{CH}_{2}\right)_{n}-\mathrm{NH}_{2} \underset{\text { 2. } \mathrm{POCl}_{3} / \mathrm{NEt}_{3}}{\longrightarrow} \mathrm{\textrm {HCO } _ { 2 } \mathrm { Et }} \longrightarrow\left(\mathrm{CH}_{2}\right)_{n}-\mathrm{NC} \\
& \text { 3a, } n=6,66 \% \\
& \text { 3b, } n=7,68 \% \\
& \text { 3c, } n=8,72 \% \\
& \text { 3d, } n=10,71 \% \\
& \text { 3e, } n=12,67 \% \\
& 3 a-e
\end{aligned}
$$

Scheme 2: Synthesis of starting diisocyanides $3 a-3 e$

We found that these diisocyanides $\mathbf{3}$ participate successfully in the catalytic three-component reaction via a modified List procedure [25]. Diamides 4 with benzyl protective groups were synthesized in moderate to good yields under mild conditions. There is no obvious dependence of yield on the length of the carbon chain in 3; aliphatic aldehydes gave better results in comparison to aromatic aldehydes (Scheme 3). Obviously, the suggested approach is an efficient and short method to form the skeleton of the target diamides. The benzyl groups can be easily 
removed from compounds $\mathbf{4}$ by the standard hydrogenolysis procedure. For example, using $\mathrm{Pd} / \mathrm{C}$ as catalyst we obtained the target peptidomimetics $\mathbf{5}$ in up to $90 \%$ yield. Thus, we synthesized a number of racemic peptidomimetics $\mathbf{4}$ and $\mathbf{5}$, containing aliphatic or aromatic groups as well as various aliphatic linkers. With these diamides in hand we began the investigation of their biological activity.

$3 \underset{\mathrm{a}}{\stackrel{\text { Ugi }}{\longrightarrow}}$<smiles>[R]C(NCc1ccccc1)C(=O)NC</smiles>

4a, $\mathrm{R}=\mathrm{iPr}, n=6,73 \%$

4b, $\mathrm{R}=\mathrm{iPr}, n=7,90 \%$

4c, $\mathrm{R}=\mathrm{iPr}, n=8,88 \%$

4d, $\mathrm{R}=\mathrm{iPr}, n=10,92 \%$<smiles>[R]C(N)CCCCCCCCCNC(=O)C([R])N</smiles>

Currently, real-time PCR is the better method for the quantitation of the target nucleic acids because of its high specificity and sensitivity of up to a few genome equivalents in a complex mixture [26]. In the present work, ribonuclease activity of the new synthesized compounds was studied in vitro by cleavage of the total cellular and the tick-borne encephalitis virus (TBEV) full-length genomic RNA isolated from infected mouse brain, with subsequent detection by RT-qPCR (TBEV is a human pathogenic member of the Flavivirudae family of RNA-containing viruses of positive polarity).

Complete cleavage of $2 \mu \mathrm{g}$ of cellular RNA including $10^{5}$ genome equivalents of the TBEV full-length RNA was observed after incubation of the total RNA from the virusinfected mouse brain with $2.5 \mathrm{mM}$ aqueous solutions of peptidomimetics 5a-g for 2 hours at $37{ }^{\circ} \mathrm{C}$. Denaturating electrophoresis in SDS-agarose gel revealed complete cleavage of the total RNA (Supporting Information File 1, Figure S1) and RT-real time PCR showed complete destruction of the TBEV RNA (Figure 2).

Compounds 5e and $\mathbf{5 g}$, the most hydrophobic among synthesized substances, might potentially penetrate through cellular or viral membranes and therefore the dependence of RNA cleavage on the concentration of the peptidomimetics was studied in detail. The concentration of compounds $\mathbf{5 e}$ and $\mathbf{5 g}$, optimal for RNA cleavage, was determined by varying the

Scheme 3: Synthesis of new aRNAses. Conditions: a. RCHO (3 eqiuv), $\mathrm{BnNH}_{2}$ (3 equiv), $\mathrm{PhP}(\mathrm{OH})_{2}$ (1 equiv), r.t.; b. $\mathrm{Pd} / \mathrm{C}, 5 \%$, $\mathrm{HCOONH} \mathrm{H}_{4}, \mathrm{MeOH} / \mathrm{H}_{2} \mathrm{O}$, reflux.

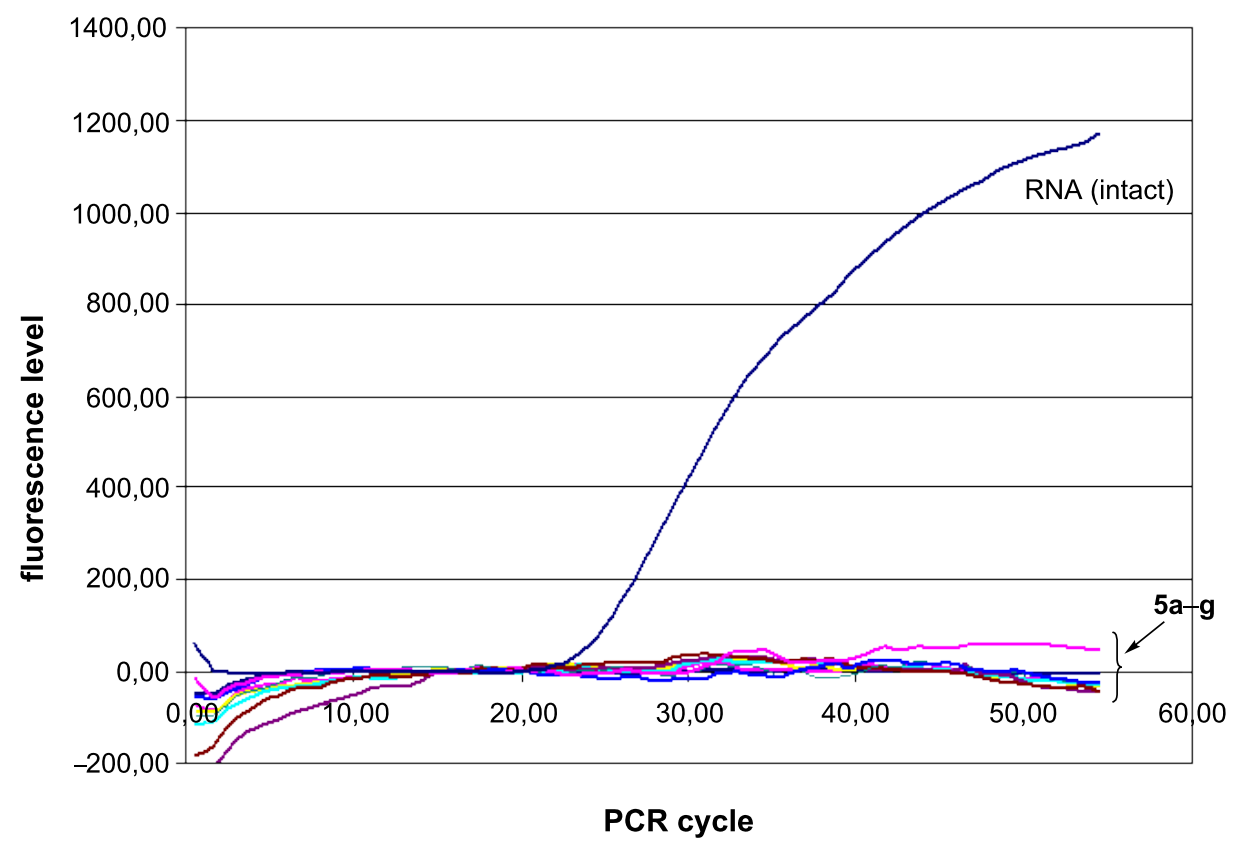

Figure 2: Results of RT-qPCR of the TBEV RNA cleavage products in presence of $2.5 \mathrm{mM}$ peptidomimetics $5 \mathrm{a}-\mathrm{g}$ at $37^{\circ} \mathrm{C}$ for 2 hours in $\mathrm{H}_{2} \mathrm{O}$. 
concentration from $2.5 \times 10^{-3}$ to $2.5 \times 10^{-7} \mathrm{M}$ (Supporting Information File 1, Figure S2 A and B). Dependence of optimal RNA cleavage on the concentration of peptidomimetics was not evident: Complete RNA cleavage of $2 \mu \mathrm{g}$ RNA was observed at a concentration of $2.5 \mathrm{mM}$ for both $5 \mathrm{e}$ with an aliphatic substituent and $\mathbf{5 g}$ with an aromatic one.

Ribonuclease activity of the compounds $\mathbf{5 e}-\mathbf{e}$ and $\mathbf{5 g}$ at $2.5 \mathrm{mM}$ concentration was assayed in cultural medium RPMI 1640 and compared cleavage in $\mathrm{H}_{2} \mathrm{O}$. All artificial RNases cleaved RNA more efficiently in water than in RPMI 1640 (Figure 3 and Figure 4). Results of RT-real time PCR (Figure 3) and electrophoresis RT-qPCR products in $2 \%$ TBE-agarose gel (Figure 4) showed varying degrees of destruction of the TBEV RNA, respectively.

To analyze DNase activity of the novel compounds, both double-stranded circular recombinant plasmid DNA with cloned full-length TBEV copy of genome and single-stranded cDNA after reverse transcription of the TBEV RNA from the infected mouse brain with random $\mathrm{N}_{6}$ primer was used. No destruction of single-stranded cDNA was observed after incubation with $2.5 \mathrm{mM}$ solutions of compounds $\mathbf{5 e}$ or $\mathbf{5 g}$ for 2 hours at $37^{\circ} \mathrm{C}$ (Supporting Information File 1, Figure S3). However, these compounds could partly cleave double-stranded plasmid DNA (Supporting Information File 1, Figure S4).

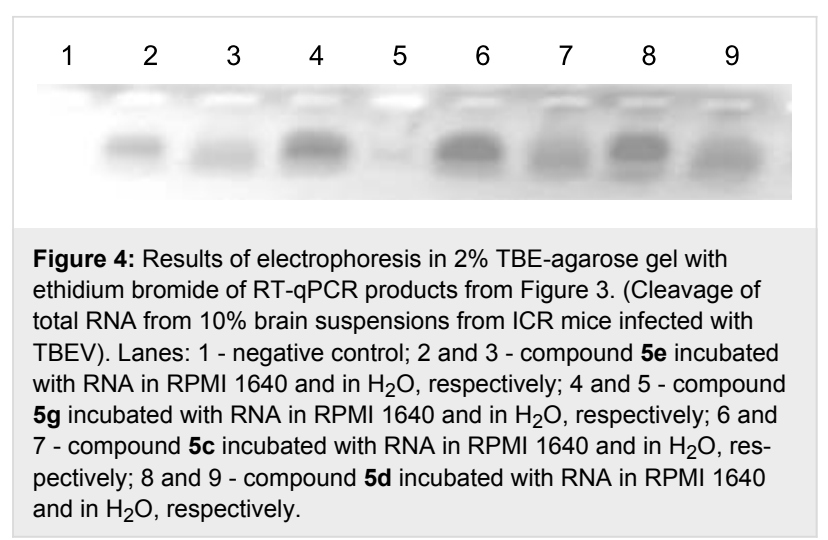

Generally, all synthesized compounds were shown to be able to cleave completely single-stranded RNA but not single-stranded cDNA or hybrid of RNA with cDNA after reverse transcription irrespective of the structures of their substituents and the length of polymethylene linkers. Double-stranded circular plasmid DNA was partially destroyed possibly because of singlestranded DNA breaks. The mechanism has been previously shown for several artificial metal-free [27] and metal-dependent nucleases [28]. A further study of the TBEV RNA cleavage, both in extracellular virions and within infected cells as well as specific cleavage of only viral RNA, is required. Further investigations of developed artificial RNases are in progress.

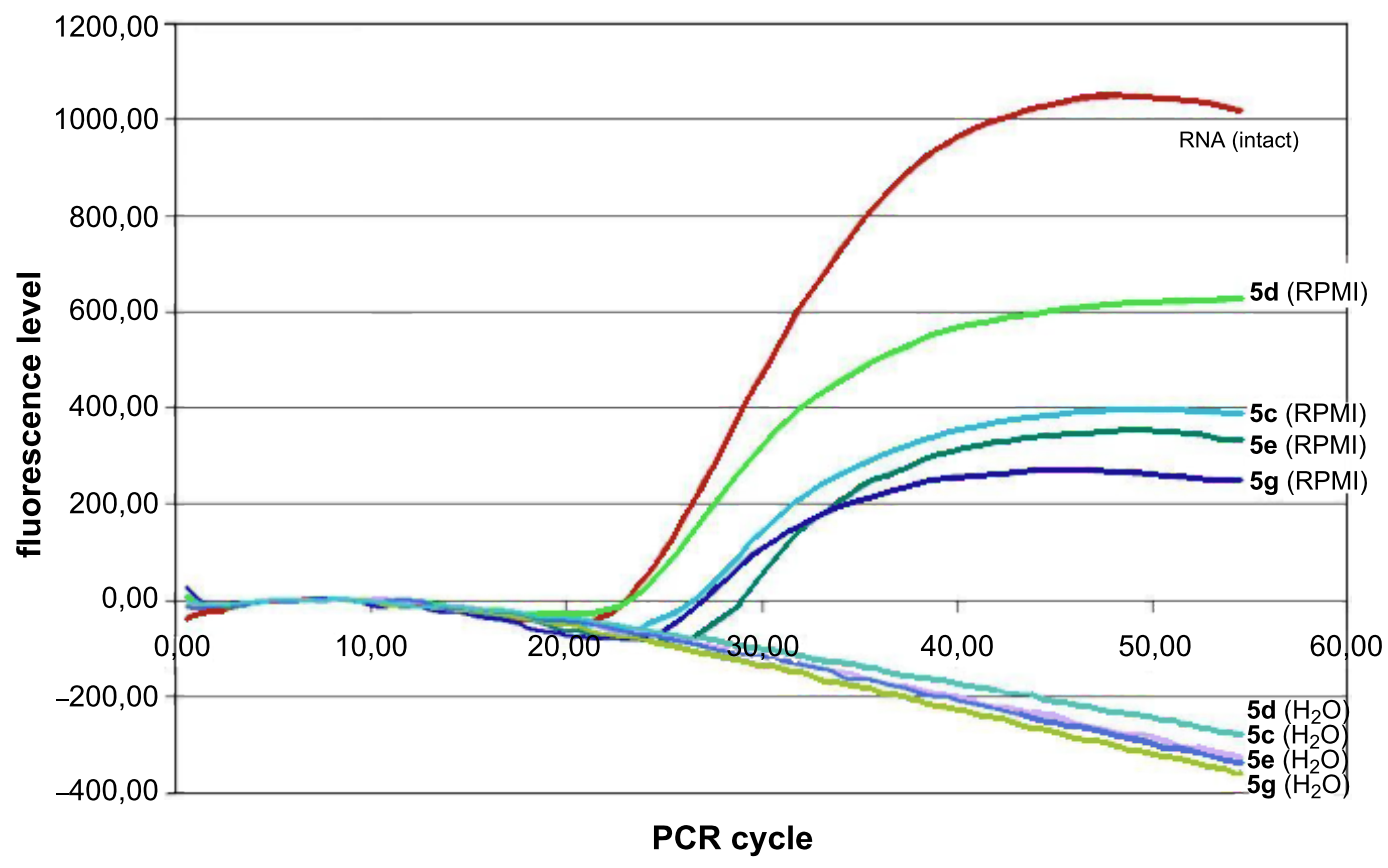

Figure 3: Results of RT-qPCR of the TBEV RNA cleavage products in the presence of $2.5 \mathrm{mM}$ peptidomimetics after incubation in $\mathrm{H}_{2} \mathrm{O}$ and in cultural medium RPMI 1640. 


\section{Conclusion}

New artificial nucleases based on diamides containing two amino acid residues connected by aliphatic linkers were synthesized by a catalytic three-component Ugi-type reaction and subsequent deprotection. To quantitative cleavage of any nucleic acids, including single-stranded RNA and cDNA as well as double-stranded circular plasmid DNA, high-throughput RT-qPCR was developed and used. All synthesized compounds were shown to be able to cleave completely single-stranded RNA but not single-stranded cDNA or hybrid of RNA with cDNA after reverse transcription irrespective of the structure of their substituents and the length of the polymethylene linker.

\section{Experimental}

\section{General procedure for the synthesis of diiso- cyanides 3}

A solution of the corresponding diamine $(0.1 \mathrm{~mol})$ in ethyl formate $(100 \mathrm{~mL})$ was heated under reflux for $5 \mathrm{~h}$. The reaction mixture was concentrated in vacuo. The resulting formamide (without additional purification) was suspended in anhydrous dichloromethane $(200 \mathrm{~mL})$ and triethylamine $(51 \mathrm{~g}, 0.5 \mathrm{~mol})$ added. The mixture was cooled to $0{ }^{\circ} \mathrm{C}$ and $\mathrm{POCl}_{3}(0.21 \mathrm{~mol}$, $32 \mathrm{~g}$ ) added dropwise at such a rate that the reaction temperature remained below $0{ }^{\circ} \mathrm{C}$. The mixture was stirred for $2 \mathrm{~h}$. The reaction mixture was poured into ice-water $(500 \mathrm{~mL})$ containing $\mathrm{K}_{2} \mathrm{CO}_{3}(100 \mathrm{~g})$ maintaining the temperature below $25{ }^{\circ} \mathrm{C}$. The resulting emulsion was stirred for $1 \mathrm{~h}$ at $\mathrm{rt}$. The organic layer was separated, the aqueous layer extracted with $\mathrm{CH}_{2} \mathrm{Cl}_{2}(2 \times 50 \mathrm{~mL})$, and the combined organic layers were dried $\left(\mathrm{K}_{2} \mathrm{CO}_{3}\right)$, purified by flash chromatography and concentrated in vacuo. The diisocyanide was obtained as a dark oil.

1,6-Diisocyanohexane (3a): Yield 66\%, dark oil, $R_{\mathrm{f}} 0.8$ (hexane/EtOAc 2:1); ${ }^{1} \mathrm{H}$ NMR (400 MHz, $\mathrm{CDCl}_{3}$ ) $\delta 1.39-1.47$ $\left(\mathrm{m}, 4 \mathrm{H}, \quad\left(\mathrm{CH}_{2} \mathrm{CH}_{2} \mathrm{CH}_{2} \mathrm{NC}\right)_{2}\right), 1.55-1.73(\mathrm{~m}, 4 \mathrm{H}$, $\left.\left(\mathrm{CH}_{2} \mathrm{CH}_{2} \mathrm{CH}_{2} \mathrm{NC}\right)_{2}\right), 3.30-3.40\left(\mathrm{~m}, 4 \mathrm{H},\left(\mathrm{CH}_{2} \mathrm{CH}_{2} \mathrm{CH}_{2} \mathrm{NC}\right)_{2}\right)$; ${ }^{13} \mathrm{C} \mathrm{NMR}\left(100 \mathrm{MHz}, \mathrm{CDCl}_{3}\right) \delta 155.6(\mathrm{t}, J=5.9 \mathrm{~Hz}, \mathrm{NC}), 41.1$ $\left(\mathrm{t}, J=6.6 \mathrm{~Hz},\left(\mathrm{CH}_{2} \mathrm{CH}_{2} \mathrm{CH}_{2} \mathrm{NC}\right)_{2}\right), 28.5,25.2 ; \mathrm{IR}\left(\mathrm{cm}^{-1}\right) 2150$ (NC); Anal. calcd for $\mathrm{C}_{8} \mathrm{H}_{12} \mathrm{~N}_{2}$ : C, 70.55; H, 8.88; found: $\mathrm{C}$, 70.34; H, 8.62.

\section{General procedure for the synthesis of $\mathbf{4 a -} \mathbf{g}$}

The corresponding isocyanide 3 ( $3 \mathrm{mmol})$ and phenyl phosphinic acid ( $3 \mathrm{mmol}, 441 \mathrm{mg}$ ) were added to a mixture of the aldehyde (9 mmol) and benzylamine (9 mmol, $963 \mathrm{mg})$ in $\mathrm{CH}_{2} \mathrm{Cl}_{2}$ or $\mathrm{MeOH}(30 \mathrm{~mL})$. The mixture was stirred for $48 \mathrm{~h}$ at $\mathrm{rt}$, the solvent removed in vacuo and the residue purified by column chromatography (hexane/ethyl acetate 1:1). The product (colorless oil or white solid) can be converted into the corresponding hydrochloride by treatment with gaseous $\mathrm{HCl}$ in $\mathrm{MeOH}$.
Compound 4a: The reaction was carried out in $\mathrm{CH}_{2} \mathrm{Cl}_{2}$, yield $73 \%$; colorless oil; $R_{\mathrm{f}} 0.4$ (hexane/EtOAc $1: 1$ ); ${ }^{1} \mathrm{H}$ NMR (400 $\left.\mathrm{MHz}, \mathrm{CDCl}_{3}\right) \delta 0.86\left(\mathrm{~d}, J=7.1 \mathrm{~Hz}, 6 \mathrm{H}, 2 \times \mathrm{CH}_{3}\right), 0.94$ $\left(\mathrm{d}, J=7.1 \mathrm{~Hz}, 6 \mathrm{H}, 2 \times \mathrm{CH}_{3}\right), 1.29-1.36(\mathrm{~m}, 4 \mathrm{H}$, $\left.\left(\mathrm{CH}_{2} \mathrm{CH}_{2} \mathrm{CH}_{2} \mathrm{NHCO}\right)_{2}\right), 1.44-1.52 （ \mathrm{~m}, 4 \mathrm{H}$, $\left.\left(\mathrm{CH}_{2} \mathrm{CH}_{2} \mathrm{CH}_{2} \mathrm{NHCO}\right)_{2}\right), 1.6$ (br s, $\left.2 \mathrm{H}, 2 \times \mathrm{NH}\right), 2.06-2.15(\mathrm{~m}$, $\left.2 \mathrm{H}, 2 \times \mathrm{CH}\left(\mathrm{CH}_{3}\right)_{2}\right), 2.95(\mathrm{~d}, J=4.3 \mathrm{~Hz}, 2 \mathrm{H}, 2 \times \mathrm{CH})$, 3.17-3.30 (m, $\left.4 \mathrm{H},\left(\mathrm{CH}_{2} \mathrm{CH}_{2} \mathrm{CH}_{2} \mathrm{NHCO}\right)_{2}\right), 3.68$ (AB-system, $J$ $\left.=13.1 \mathrm{~Hz}, 4 \mathrm{H}, 2 \times \mathrm{CH}_{2} \mathrm{Ph}\right), 7.20-7.35(\mathrm{~m}, 12 \mathrm{H}, \mathrm{Ph}, 2 \times \mathrm{NH})$; ${ }^{13} \mathrm{C}$ NMR $\left(100 \mathrm{MHz}, \mathrm{CDCl}_{3}\right) \delta 173.3,139.6,128.6,128.1$, 127.3, 67.9, 53.5, 38.6, 31.2, 29.7, 26.5, 19.6, 17.7; IR $\left(\mathrm{cm}^{-1}\right)$ $1640(\mathrm{CONH}), 3300$ (br, CONH); ESI-MS $(\mathrm{m} / \mathrm{z})$ : $[\mathrm{M}+\mathrm{H}]^{+}$ calcd for $\mathrm{C}_{30} \mathrm{H}_{46} \mathrm{~N}_{4} \mathrm{O}_{2}$, 495.3621; found, 495.3698.

\section{Cleavage of the benzyl group}

A solution of $\mathrm{HCOONH}_{4}\left(1 \mathrm{~g}\right.$ in $\left.5 \mathrm{~mL} \mathrm{H}_{2} \mathrm{O}\right)$ was added to a solution of the corresponding amide $4(1 \mathrm{mmol})$ in $10 \mathrm{~mL}$ of $\mathrm{MeOH}$. The catalyst, $\mathrm{Pd} / \mathrm{C},(100 \mathrm{mg}, 5 \%)$ was added and the mixture heated under reflux for $5 \mathrm{~h}$. The mixture was concentrated and treated with aqueous $\mathrm{K}_{2} \mathrm{CO}_{3}$. The product was extracted with $\mathrm{CH}_{2} \mathrm{Cl}_{2}(3 \times 30 \mathrm{~mL})$, the organic layer dried $\left(\mathrm{K}_{2} \mathrm{CO}_{3}\right)$ and concentrated in vacuo. The residue was purified by column chromatography $\left(\mathrm{CH}_{2} \mathrm{Cl}_{2} / \mathrm{MeOH} 10: 1\right)$. The resulting product (colorless oil or white solid) can be converted into corresponding hydrochloride by treatment with gaseous $\mathrm{HCl}$ in $\mathrm{MeOH}$.

Compound 5a: Yield 67\%; colorless oil; $R_{\mathrm{f}} 0.6\left(\mathrm{CH}_{3} \mathrm{CN} /\right.$ $\mathrm{EtOH} / \mathrm{NH}_{3}$ 80:12:8); ${ }^{1} \mathrm{H}$ NMR $\left(400 \mathrm{MHz}, \mathrm{CDCl}_{3}\right) \delta 0.81(\mathrm{~d}$, $\left.J=7.1 \mathrm{~Hz}, 6 \mathrm{H}, 2 \times \mathrm{CH}_{3}\right), 0.97\left(\mathrm{~d}, J=7.1 \mathrm{~Hz}, 6 \mathrm{H}, 2 \times \mathrm{CH}_{3}\right)$, 1.30-1.40 (m, 4H, $\left.\left(\mathrm{CH}_{2} \mathrm{CH}_{2} \mathrm{CH}_{2} \mathrm{NHCO}\right)_{2}\right), 1.44-1.52(\mathrm{~m}, 4 \mathrm{H}$, $\left.\left(\mathrm{CH}_{2} \mathrm{CH}_{2} \mathrm{CH}_{2} \mathrm{NHCO}\right)_{2}\right), 2.26-2.36\left(\mathrm{~m}, 2 \mathrm{H}, 2 \times \mathrm{CH}\left(\mathrm{CH}_{3}\right)_{2}\right)$, 3.17-3.30 (m, 6H, $\left.2 \times \mathrm{CH},\left(\mathrm{CH}_{2} \mathrm{CH}_{2} \mathrm{CH}_{2} \mathrm{NHCO}\right)_{2}\right), 7.26-7.33$ $(\mathrm{m}, 2 \mathrm{H}, 2 \times \mathrm{NH}) ;{ }^{13} \mathrm{C} \mathrm{NMR}\left(100 \mathrm{MHz}, \mathrm{CDCl}_{3}\right) \delta 174.3,60.2$, 38.6, 31.2, 29.7, 26.5, 19.6, 17.7; IR $\left(\mathrm{cm}^{-1}\right) 1638$ (CONH), 3290 (br, NH, $\mathrm{NH}_{2}$ ); ESI-MS $(\mathrm{m} / \mathrm{z})$ : $[\mathrm{M}+\mathrm{H}]^{+}$calcd for $\mathrm{C}_{16} \mathrm{H}_{34} \mathrm{~N}_{4} \mathrm{O}_{2}, 314.2682$; found, 314.2670.

\section{Supporting Information}

\section{Supporting Information File 1}

General information, procedures, spectral data of all compounds, results of bioassay, and copies of selected NMR spectra.

[http://www.beilstein-journals.org/bjoc/content/ supplementary/1860-5397-7-131-S1.pdf]

\section{Acknowledgements}

The study was partly supported by SB RAS- 83,88 and RFBR09-04-01483. 


\section{References}

1. Zenkova, M. A., Ed. Artificial Nucleases; Nucleic Acids and Molecular Biology, Vol. 13; Springer-Verlag: Berlin Heidelberg, 2004.

2. Makarov, A. A.; Ilinskaya, O. N. FEBS Lett. 2003, 540, 15-20. doi:10.1016/S0014-5793(03)00225-4

3. Leland, P. A.; Raines, R. T. Chem. Biol. 2001, 8, 405-413.

4. Silnikov, V. N.; Vlassov, V. V. Russ. Chem. Rev. 2001, 70, 491-508.

5. Niittymäki, T.; Lönnberg, H. Org. Biomol. Chem. 2006, 4, 15-25. doi:10.1039/b509022a

6. Lu, Z. L.; Liu, C. T.; Neverov, A. A.; Brown, R. S. J. Am. Chem. Soc. 2007, 129, 11642-11652. doi:10.1021/ja073780l

7. Koroleva, L. S.; Kuz'min, V. E.; Muratov, E. N.; Artemenko, A. G.; Silnikov, V. N. Russ. J. Bioorg. Chem. 2008, 34, 442-452.

8. Niittymäki, T.; Virta, P.; Ketomäki, K.; Lönnberg, H. Bioconjugate Chem. 2007, 18, 1583-1592. doi:10.1021/bc070071o

9. Michaelis, K.; Kalesse, M. Angew. Chem., Int. Ed. 1999, 38, 2243-2245. doi:10.1002/(SICI)1521-3773(19990802)38:15<2243::AID-ANIE2243>3 .0.CO;2-V

10. Scheffer, U.; Strick, A.; Ludwig, V.; Peter, S.; Kalden, E.; Göbel, M. W. J. Am. Chem. Soc. 2005, 127, 2211-2217. doi:10.1021/ja0443934

11. Giegé, R.; Felden, B.; Zenkova, M. A.; Sil'nikov, V. N.; Vlassov, V. V. Methods Enzymol. 2000, 318, 147-165. doi:10.1016/S0076-6879(00)18050-4

12. Nosik, D. N.; Lavrukhina, L. A.; Kondrashina, N. G.; Garaev, T. M.; Shibnev, V. A. Problems of Virology 2010, 3, 41-43.

13. Zhdan, N. S.; Kuznetsova, I. L.; Vlassov, A. V.; Sil'nikov, V. N.; Zenkova, M. A.; Vlassov, V. V. Russ. J. Bioorg. Chem. 1999, 25, 639-647.

14. Kuznetsova, I. L.; Zhdan, N. S.; Zenkova, M. A.; Vlassov, V. V.; Sil'nikov, V. N. Russ. Chem. Bull. 2004, 53, 455-462. doi:10.1023/B:RUCB.0000030824.26304.cb

15. Koroleva, L. S.; Donina, A. A.; Tamkovich, N. V.; Kovalev, N. A.; Zenkova, M. A.; Sil'nikov, V. N. Russ. Chem. Bull. 2005, 54, 2682-2691. doi:10.1007/s11172-006-0176-4

16. Konevetz, D. A.; Mironova, N. L.; Beck, I. E.; Zenkova, M. A.; Shishkin, G. V.; Vlassov, V. V.; Silnikov, V. N. Russ. J. Bioorg. Chem. 2002, 28, 331-341. doi:10.1023/A:1019504227151

17. Koroleva, L. S.; Svischeva, N. S.; Rustamova, L. M.; Gribkova, N. V.; Silnikov, V. N. Amino Acids 2009, 37, S64-S65.

18. Koroleva, L. S.; Svishcheva, N. S.; Burakova, E. A.; Gribkova, N. V.; Schmeleva, N. P.; Rustamova, L. M.; Sabynin, V. M.; Sil'nikov, V. N. Pharm. Chem. J. 2010, 44, 679-682. doi:10.1007/s11094-011-0541-y

19. Gulevich, A. V.; Zhdanko, A. G.; Orru, R. V. A.; Nenajdenko, V. G. Chem. Rev. 2010, 110, 5235-5331. doi:10.1021/cr900411f

20. Gulevich, A. V.; Shevchenko, N. E.; Balenkova, E. S.; Röschenthaler, G.-V.; Nenajdenko, V. G. Synlett 2009, 403-406. doi:10.1055/s-0028-1087529

21. Zhdanko, A. G.; Gulevich, A. V.; Nenajdenko, V. G. Tetrahedron 2009, 65, 4692-4702. doi:10.1016/j.tet.2009.04.030

22. Gulevich, A. V.; Shpilevaya, I. V.; Nenajdenko, V. G. Eur. J. Org. Chem. 2009, 3801-3808. doi:10.1002/ejoc.200900330

23. Zhdanko, A. G.; Nenajdenko, V. G. J. Org. Chem. 2009, 74, 884-887. doi:10.1021/jo802420c

24. Nenajdenko, V. G.; Gulevich, A. V.; Sokolova, N. V.; Mironov, A. V.; Balenkova, E. S. Eur. J. Org. Chem. 2010, 1445-1449. doi:10.1002/ejoc.200901326

25. Pan, S. C.; List, B. Angew. Chem., Int. Ed. 2008, 47, 3622-3625. doi:10.1002/anie.200800494
26. Bustin, S. A. J. Mol. Endocrinol. 2000, 25, 169-193. doi:10.1677/jme.0.0250169

27. Li, Y.; Zhao, Y.; Hatfield, S.; Wan, R.; Zhu, Q.; Li, X.; McMills, M.; Ma, Y.; Li, J.; Brown, K. L.; He, C.; Liu, F.; Chen, X. Bioorg. Med. Chem. 2000, 8, 2675-2680. doi:10.1016/S0968-0896(00)00208-X

28. Branum, M. E.; Tipton, A. K.; Zhu, S.; Que, L., Jr. J. Am. Chem. Soc. 2001, 123, 1898-1904. doi:10.1021/ja0010103

\section{License and Terms}

This is an Open Access article under the terms of the Creative Commons Attribution License

(http://creativecommons.org/licenses/by/2.0), which permits unrestricted use, distribution, and reproduction in any medium, provided the original work is properly cited.

The license is subject to the Beilstein Journal of Organic Chemistry terms and conditions: (http://www.beilstein-journals.org/bjoc)

The definitive version of this article is the electronic one which can be found at: doi:10.3762/bjoc.7.131 